\title{
Prameny Eróta v Platónově Symposiu
}

\section{Tomáš Vítek}

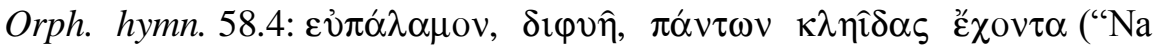
háčcích všechny vodís, ty šibale se dvěma rody")

Není tajemství, že Platón pro své pověstné filosofické mýty využíval reálný mythologický, literární, kultický i ikonografický materiál. Naproti tomu je dosud poněkud nejasné, $v$ jaké míře to činil a co přesně ho k takovému prŕístupu motivovalo. Přívlastkem "filosofický" se zpravidla míní, že takto označený mýthos je obrazným opisem myšlenkového tvaru, který by byl v jazyce logu obtížně argumentovatelný nebo pochopitelný. Na takovém pohledu jistě leccos je, ale přesto tak trochu uzavírá př́stup k otázce, zda jsou Platónovy mýthy opravdu umělé, tj. nově vymyšlené příběhy složené $z$ účelově vybraných a vesměs silně transformovaných střípků starší tradice, anebo spíše svébytným, ale nikoli svévolně sřetězeným a využívaným souborem motivů, které jen jiným způsobem a v jiném prostředí vyjadřují nebo dále rozvíjejí tradiční mythologéma. Tato otázka má svou váhu pro celé Platónovo dílo, ale obzvláště pro Symposion, nebot' nikoli nevýstižně Reinhardt soudí, že celý tento spis představuje mýthos, v němž se rozplývá jinde tak ostře vedená hranice mezi jím a logem. ${ }^{\mathrm{i}}$ Avšak stejně tak by se dalo říci, že mýthos je v Symposiu natolik ve službách logu, že stává nejen jeho součástí, ale i jeho projevem, stínem jeho dne, lunosvitem jeho noci. ${ }^{\text {ii }}$

\footnotetext{
${ }^{\text {i }}$ Reinhardt 1927, s. 54. Srv. např. Protag. 324d6-7: “O tomto, Sókrate, už nebudu

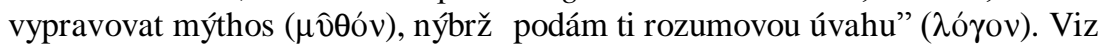
dále Resp. 522a, Protag. 320c, Tim. 26e, Phaed. 61b.

${ }^{i i}$ Srv. Friedländer 1954, I.189-190, jenž vidí v prvních pěti řečech projevy mýtu a v následujících dvou cestu k logu.
} 
Následující výklad si klade za cíl přispět na př́kladu Eróta alespoň částečně k objasnění způsobu, jakým Platón nakládal s tradičními mythologickými, náboženskými a literárně-filosofickými motivy. Nebylo ovšem možné - a snad ani potřebné - sledovat všechny podněty a předlohy, s nimiž pracoval či pracovat mohl, zvláště když se řada z nich objevuje $\mathrm{v}$ různém světle $\mathrm{a} \mathrm{v}$ různých aspektech $\mathrm{i}$ na jiných místech jeho díla. Ponechal jsem stranou jak prameny jednotlivých řečí o Erótovi, jimiž Platón parodoval hlavní myšlenkové směry či styly dobového myšlení, tak víceméně i jeho koncepci Eróta v ostatních dialozích. Ale ani v rámci Symposia se nevěnuji všem zmínkám, narážkám a souvislostem, ani je nepodávám stejně důkladně. In illo puncto jsem se ř́idil dvěma kritérii: za prvé stupněm známosti a odborné rozpracovanosti motivů (čím je větší, tím menší pozornost vyžaduje), za druhé jejich nosností pro celkový záměr článku.

Platónovu velepíseň na Eróta - a také základní přístup k celému tématu jakoby předznamenává nenápadná věta, kterou Sókratés pronáší ke krásnému Agathónovi hned po svém příchodu do jeho domu (Symp. 175d37): "Bylo by dobře, Agathóne, kdyby byla moudrost něco takového, že by při vzájemném dotýkáni přetékala mezi námi z plnějšího do prázdnějšího jako voda v nádobách, která po proužku vlny pretéká z plnější nádoby do prázdnější." Zde nelze nevzpomenout hravé etymologie Erótova jména, které Platón odvozoval od "vtékání dovnitř”" prostřednictvím očí, ${ }^{i}$ a výměru touhy jako proudu, jenž od miláčka plyne k milovníku a vniká do něj, aby se vrátil nazpět ke svému zdroji. ${ }^{\text {ii }}$

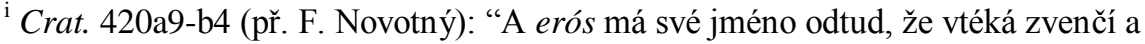
že tento tok není vlastní tomu, kdo jej má, nýbrž uvádí se dovnitř skrze oči; proto, od toho vtékání byla láska za starodávna nazývána esros - užívali jsme totiž $o$ místo $o ́$ - nyní však je nazvána erós pro změnu $o \mathrm{v} o ́$."

ii Phaedr. 255c1-7 (př. F. Novotný): "Tu již pramen onoho proudu, jejž Zeus ... pojmenoval himeros (touha), bohatě plyne k milovníku a jednak vnikne do něho, jednak, když už je zcela naplněn, odtéká ven; a jako se vítr nebo nějaká ozvěna odráží od hladkých a tvrdých stěn a nese se zpět tam, odkud vyšla, tak se ten proud

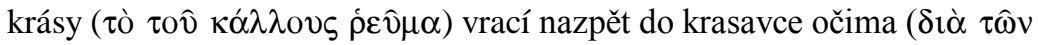
ỏ $\mu \alpha \alpha ́ \tau \omega v)$; tudy vchází podle své přirozenosti do duše."
} 
V tomto zvláštním obrazu se odráží předfilosofické pojetí touhy, která byla varchaické poesii standardně označována epitetem $\lambda v \sigma \imath \mu \varepsilon \lambda \eta ́ s$, "rozpouštějící údy". 'Už Hésiodos zdůvodňoval přitažlivost Charitek tím, že se "zpod jejich zdvižených víček se řinul eros, jenž údy / rozpouští". ii Podobně Homér líčí, že když ženiši spatřili naparáděnou Pénelopu, "roztekla se jim kolena", ježto jim eros ovládl mysl. ${ }^{\text {iii }}$ Tento "tekutý" Erós zaplavoval nitro člověka a zbavoval ho síly, nebot' přesměrovával jeho obsah a aktivitu do míst spjatých se sexualitou tak intenzivně, že to na jiných místech vyvolávalo slabost: podklesávání v kolenou, ochablost, roztékání údů. ${ }^{i v}$ Nitro a sílu člověka vytvářely hlavní tělesné tekutiny: krev, morek (mozek), sperma a slzy. Tyto tekutiny ztělesňovaly život, takže jejich ubývání či ztrácení eo ipso znamenalo jeho oslabování, chřadnutí, přibližování se smrti: odtud byly láska, opilství, nemoc, spánek a smrt nerozdílně lysimelés. ${ }^{\mathrm{V}}$ Obzvláštní nebezpečí se skrývalo v očích, poněvadž člověku užíraly život nejen slzy (jako Odysseovi u nymfy Kalypsó), ale i spermatem prosycený pohled, který očima vylétal ven - stejně nenávratně jako ejakulát - za předmětem touhy, ve snaze prodrat se do jeho nitra a připoutat ho k sobě ${ }^{\text {vi }}$ Tomu se původně rríkalo erós, a proto se také mluvilo o erótovi té či oné osoby. ${ }^{i}$

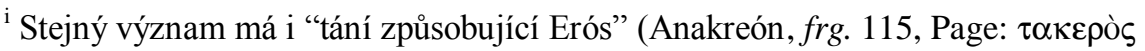
$\delta$ 'E $\omega \varsigma)$.

ii Theog. 910-911.

iii Od. XVIII.202-203: “Ženichům kolena ochabla ( $\lambda$ v́

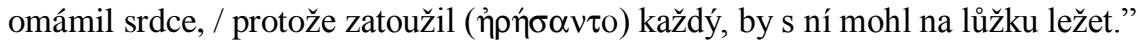
${ }^{i v}$ Alkmán, frg. 3.13.61-62, Campbell: "S údy rozpouštějící touhou $(\lambda v \sigma \mu \varepsilon \lambda \varepsilon \square \tau \varepsilon$ $\pi$ ó $\sigma \omega)$, s větší mocí působit tání, / než možné je spánku či smrti, (na mě?) se dívá." Archilochos, frg. 103, Edmonds: "Taková po lásce touha se vplížila pod (moje) srdce, / že zalila oči (mi) hustou mlhou / a ukradla myšlenky něžné z hrudi.” Srv.

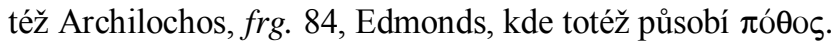

${ }^{v}$ Láska: viz níže; opilství a nemoc: Anth. Pal. XI.414; spánek: Od. XX.57, XXIII.343, Moschos II.4;smrt: Eurípidés, Suppl. 47.

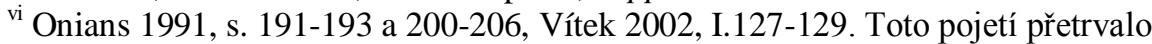
až do klasické doby, srv. DK 88 B 11.19 = Gorgiás, Hel. 19 (upr. př. B. Borecký): "Co je proto podivného na tom, jestliže se zrak Heleny potěšil při pohledu na tělo Paridovo a předal její duši touhu a prudkou žádost (eróta)? Jestliže je (Erós) bohem <a má $>$ božskou moc bohů, jak by se jí ten, kdo je slabší, mohl ubránit a
} 
Sókratés možnost přetékání moudrosti z jednoho člověka do druhého ironicky zlehčuje, ale ve své řeči podobně probíhající prèdání Eróta v metafoře plození připouští (206e-212a), ba dokonce ho identifikuje s touhou po moudrosti a filosofování (210d-e). Jeho úvodní letmé odmítnutí má tedy erotickou povahu, je vpravdě skrytým a velmi propracovaným přitakáním, jehož dvojznačnost neodmyslitelně zahrnuje i popření. Podobného druhu se zdá být i Eryximachovo odmítání opilosti (které se na konci hostiny obrátí ve všeobecnou omámenost alkoholem), nebot' účinky nemírného pití a Eróta byly často uváděny do ekvivalence. ${ }^{\text {ii }}$

V první řeči Faidros prohlašuje Eróta za nejstaršího boha, který nemá rodiče (178b), odvolávaje se přitom výslovně na starší prameny. Prvním z nich byl Hésiodos, jenž Eróta představil jako personalizovanou kosmickou mocnost, která se objevila spolu s Gáiou a Tartarem hned po počátečním Chaosu. ${ }^{\text {iii }}$ Následně Faidros poukázal na protofilosofa Akúsiláa z Argu (cca 6/5. st. př. n. 1.), jenž prý podobně jako Hésiodos předpokládal po prvotním Chaosu dvojici Gé a Erós. ${ }^{\text {iv }}$ Podle ostatních pramenů však Akúsiláos jako druhou generaci po Chaosu postuloval pár Erebos a Nýx, který následně zplodil Eróta, Aithér a Métis, ${ }^{\mathrm{V}}$ To se zdá být pravděpodobněǰší, poněvadž tato struktura více konvenuje s presókratickými kosmologiemi, a navíc $\mathrm{v}$ ní principy neuspořádanosti, temnoty a chthonicity (Chaos, Erebos, Nýx) rodí řád, světlo a soudružnost

uchránit?” Ještě Aristotelés, De gen. anim. 747a13, pokládal oko za nejsexuálnější část těla, která je obdařena největší koncentrací semene.

${ }^{i}$ Hésiodos, frg. 105, Rzach: "Protože trýznil ho mocný eros překrásné Aiglé." Anakreón, frg. 12.10-11, Page: "Aby přijal, ó Dionýse, mého eróta."

ii Viz např. Anakreón, frg. 32.1, Page: “Jsa zpitý erótem".

iii Theog. 120-112 (upr. př. J. Nováková): “A s ní (tj. Gáiou) Erós, jenž z věčných bohů je nejspanilejší, / rozpouští údy a podmaňuje si ve hrudích mysl / veškerých lidí i rozšafný rozum veškerých bohů.”

${ }^{\text {iv }}$ DK 9 B 2 = Platón, Symp. 178b8-9: S Hésiodem souhlasí i Akúsiláos, že se po Chaosu zrodily tyto dvě božské bytosti, tj. Gé a Erós."

${ }^{v}$ DK 9 B 1 = Damaskios, De princ. 124: "Zdá se mi, že Akúsiláos pokládal za první počátek Chaos, poněvadž je všude nepoznatelný. Po prvním principu následovaly dva: Erebos jako samec a Nyx jako samice... [Akúsiláos dále] ř́íká, že z jejich spojení vznikli Aithér, Erós a Métis." DK 9 B 3 = Schol. in Theocr. XIII.12: “Je nejisté, čí syn Erós je. ... Podle Akúsiláa je synem Nyx a Aithéru." 
(Erós, Aithér, Métis). Př́ičin Platónova zásahu se lze jen dohadovat, ale snad se mu Erós lépe hodil blíže počátku a jako součást páru se Zemí, což ho stavělo do role Gáina tradičního manžela Úrana a nepř́ímo spojovalo

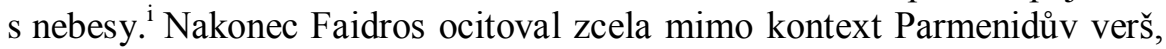
podle něhož "Erós byl smyšlen jako nejprvnější z bohů". ii

Faidrem citované ukázky nepředstavovaly jen literárně-filosofické rozvíjení hésiodovských fantazií. Jednak jsou z 5. století na vázových malbách doloženy podoby Eróta nasvědčující jeho roli nejstaršího

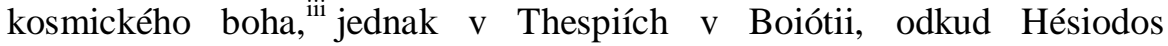

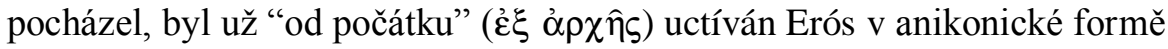
jako nejváženější z bohů, přičemž kult měl takovou sílu, že vytvořil několik filiálek a přetrval až hluboko do římské doby. ${ }^{\text {iv }}$ Také vztah milovník - miláček, jehož patronem Faidros učinil Eróta (178c-180b), se opíral o zcela reálnou předlohu. Erotický poměr mezi starším mužem a dospívajícím hochem měl zejména u Dórů i výchovný a náboženský rozměr, který přetrvával ještě i v době klasické. ${ }^{v}$ Milostné dvojice pod patronací Eróta závodily v areté a tvořívaly nejbojovnější část armád, nebot' se prý jejich členové styděli projevit jeden před druhým jakoukoli slabost. ${ }^{\text {vi }}$ Tyto vztahy tvořily nedílnou součást výchovy mnoha mladých aristokratů, kteří během svého (vojenského) výcviku závodili v areté a fyzické zdatnosti, což bylo zjevně hlavním důvodem, proč se Erós stal -

\footnotetext{
${ }^{\mathrm{i}} \mathrm{Z}$ podobných důvodů vynechal verš 118 se zmínkou o Tartaru i při výše uvedené citaci z Hésioda, srv. k tomu např. Kirk - Raven - Schofield 2004, s. 52, pozn. 24, nebo Delcourt 1958, s. 28-29.

ii DK 28 B 13. K problémům spjatým s interpretací tohoto verše srv. např. L. Tarán, Parmenides, Princeton University Press 1965, s. 250, pozn. 56, nebo A. H. Coxon, The Fragments of Parmenides, Assen - Maastricht 1986, s. 242-244.

${ }^{\text {iii }}$ Rumpf 1966, s. 314, jenž však současně připouští arbitrárnost takovýchto výkladů. Později se však takto interpretovatelní Eróti již v ikonografii neobjevují. ${ }^{\text {iv }}$ Pausaniás IX.27.1-3, Athénaios, Deipn. XIII. 561e. K thespijskému kultu srv. Furtwängler 1884/8, s. 1340-1342, Wasser 1907, s. 490, Nilsson $1967^{3}$, I.525, nebo A. Schachter, Cults of Bootia I-III, University of London 1981, I.216-219. ${ }^{v}$ Podrobněji viz E. Bethe, Die dorische Knabenliebe. Ihre Ethik und ihre Idee, in: RhM 62, 1907, s. 438-475, R. F. Willets, Cretan Cults and Festivals, London 1962, s. 116-117, Dover 1989, s. 185-196, nebo Hejduk 2007, s. 15-26.

K ikonografii srv. Hermary 1986, s. 902-903, Nr. 600-614.

${ }^{v i}$ Athénaios, Deipn. XIII, 561e-f, Plútarchos, Amat. 17, 760d-761d.
} 
spolu s Hérakleem a Hermem - i patronem gymnasií. ${ }^{\mathrm{i}} \mathrm{V}$ Athénách tento erótovský kult existoval minimálně od doby samovládce Peisistrata (tj. od poslední třetiny 6. st. př. n. 1.), jehož miláček Charmos prý bohovi poblíž Akadémie vztyčil oltářr. ${ }^{\text {ii }} \mathrm{O}$ tom všem musel Platón bezpečně vědět. ${ }^{\text {iii }}$

Pausaniás svou řeč otevírá tvrzením, že z existence dvou Afrodít nutně vyplývá i existence dvou Erótů, nebot' bohyně prý byla $\mathrm{s}$ bohem vždy pevně spjata (180c-e). To je ovšem zjevná nepravda. Ne proto, že Úrania a Pandémos v kultu nikdy nevyjadřovaly opozitní stránky bohyně, ani její nejvýznačnější manifestace, ${ }^{\text {iv }}$ ani proto, že z existence dvou Afrodít nijak nevyplývá nutnost dvou Erótů; ${ }^{\vee}$ ale $\mathrm{z}$ toho důvodu, že Platón ve svém "argumentu" rafinovaně invertoval historické pořadí premis. Tradice totiž rozlišovala dva Eróty mnohem dříve, než se v sókratovsko-platónském

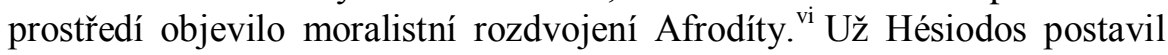
svého kosmického Eróta po bok bohyně, která se narodila až mnohem později než on z Úranova moudí ${ }^{\text {vii }}$ Nedlouho poté už lze narazit na Eróta připodobňovaného dítěti, které je Afrodítě podřízeno (viz níže). Další krok učinila Sapfó, která rozlišila nebeského Eróta, syna prvotních bohů Úrana a

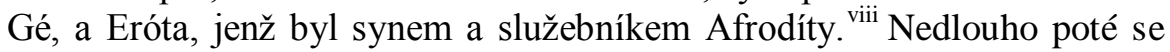

${ }^{\mathrm{i}}$ Srv. např. Ergiás, FHG IV.406, frg. 2 = Athénaios, Deipn. XIII, 561f-562a. Furtwängler 1884/8, s. 1343-1344, Wasser 1907, s. 490, Rumpf 1966, s. 322-323 (kult) a 325 (ikonografie), Dover 1989, s. 54-57.

${ }^{i i}$ Pausaniás I.30.1 (př. H. Businská): "Před vchodem do Akadémie je Erótův oltáŕ s nápisem, že z Athéňanů jej Erótovi první zasvětil Charmos.” Viz též Athénaios, Deipn. XIV, 609d, a Suda, s. v." I $\pi \pi \alpha \rho \chi 0 \varsigma$. Waser 1907, s. 492. iii Srv. např. Phaedr. 265c2-3, kde je Erós zván "dohližitelem na krásné hochy”. iv Historikové řeckého náboženství Platónovo rozdělení Afrodíty vesměs odmítají jako účelový konstrukt (Nilsson 1967, I.521, Burkert 1985, s. 155, Rudhardt 1986, s. 20-21), na tom nic nemění ani dřívější existence dvou různých genealogií bohyně.

${ }^{\mathrm{v}}$ Korektnost této dedukce napadá např. Strauss 1996, s. 63.

${ }^{v i}$ Greifenhagen 1957 s. 42-43. Xenofón, Symp. VIII.9, Apuleius, Apol. 12.1-18, Artemidóros, On. II.37, Plótinos, Enn. VI.9.9.28, aj.

vii Theog. 201-202 (př. J. Nováková): "K ní se přidružil Erós a šla s ní spanilá Touha, / jakmile přišla na svět a brala se do sboru bohů."

viii Sapfó, frg. 198, Edmonds: "Sapfó (učinila Eróta) synem Gé a Úrana;" frg. 159, Edmonds: “Afrodítě ríká Sapfó v jedné z jejích písní: 'Ty a a tvůj služebník Erós."' 
spolu s pluralizací erótků vynořil i pár Erós - Anterós, ${ }^{i}$ jenž vzešel nejspíše z Erótova kultu v gymnasiích a vyjadřoval především dvě strany pederastického vztahu milovník-miláček: ii jednu pozitivní, zasvěcenou lásce a boji, druhou temnou, postihující lásku zhrzenou a neopětovanou. ${ }^{\text {iii }}$ Platónova reinterpretace tohoto páru ve Faidru vycházela právě z tohoto tradičního pojetí, ${ }^{\text {iv }}$ at' už znal nebo neznal athénskou legendu o Melétovi a nešt’astně zamilovaném Tímagorovi, v níž Anterós vystupoval jako mstitel či ztělesnění Díké. Pokud tedy již v 6 . století byli vyprofilováni dva Eróti $\mathrm{s}$ odlišnou genealogií, hodnotou i polem působnosti, pak tvrzením o jejich původu z dvou Afrodít Platón asi nechtěl upozornit až tolik na jejich známou dvojitost či zdvojenost, jako spíše na jejich podvojnost, a tak i na podvojnost veškeré lásky. Tato podvojnost se totiž skrývá nejen v pojetí dvou Afrodít či Erótů (protože vlastnosti, které vedly kjejich rozdělení do dvou protikladů, nutně sdílejí obě nově vytvořené postavy, jen v odlišné formě a poměru), nýbrž i v pojetí božské postavy jediné, která se svou komplexností vymyká pohledu a generuje nebo zrcadlí dva stavy, které se pozorovateli zdají být protikladné.

Také Eryximachos rozlišoval dvojího Eróta, jen jeho působnost rozšíríil z člověka a jeho duše i na všechno ostatní ve světě (186a). Podle jeho názoru je dvojím Erótem vybaveno i tělo, a to jedním dobrým, díky němuž prospívá, a druhým špatným, díky němuž chřadne, či dokonce umírá (186c-

Sapfó tak byla nejspíše první, kdo výslovně rozlišil dva Eróty (viz např. Gruppe 1906, II.1071, pozn. 1).

${ }^{i}$ Pár je doložen na malbách a reliéfech od 5. st. př. n. 1. (Hermary 1986, s. 882-883, Nr. 388-395, Greifenhagen 1957, s. 40-45, Abb. 2-3 a 31-34), i když ho není snadné vždy odlišit od dvojice zápasících erótů (Hermary 1986, s. 911-912, Nr. 715). O starém reliéfu s vyobrazením páru v élidském gymnasiu hovoří i Pausaniás VI.23.3 a 5.

${ }^{i i}$ Furtwängler 1884/88, s. 1343, Waser 1907, s. 491.

iii Greifenhagen 1957, s. 43, jenž vidí v původu páru Eróta zápasníka (Anakreón, frg. 27, Diehl, Sofoklés,Trach. 441). Podrobně mapuje různé (literární) podoby a významy páru Erós - Anterós Merill 1944, s. 265-284.

${ }^{\text {iv } P h a e d r . ~ 255 d 6-e 1 ~(p r ̌ . ~ F . ~ N o v o t n y ́): ~ “ A ~ k d y z ̌ ~ t e n ~(m i l u j i ́ c i ́) ~ j e ~ p r ̌ i ́ t o m e n, ~ p r ̌ e s t a ́ v a ́ ~}$ ho týmž způsobem jako onoho bolest, avšak když je vzdálen, týmž způsobem zase touží, jako jest předmětem touhy, a je v něm Anterós, odraz Eróta.” Srv. Merill 1944, s. 267-268.

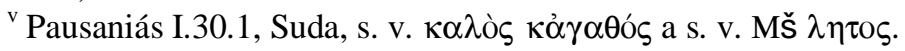


e). Také Eryximachos výslovně ocitoval jednu ze svých předloh (187a), a sice Hérakleita a jeho zlomek o harmonii lyry a luku. ${ }^{\text {i }}$ Také tento výrok je zkreslen, zejména zavedením diachronie a odmítnutím harmonie "věcí ještě se různících" (187a), a to nejspíše proto, že podle Eryximacha jsou "zdravý stav těla a nemocný nesporně různé a nepodobné” (186b). ${ }^{\text {ii }}$ Platón tak současně narážel asi i na Hérakleitův výrok o luku, jenž současně skýtá život i smrt. ${ }^{\text {iii }}$ Je známo několik zpodobení Eróta s lyrou, ${ }^{\text {iv }}$ ale luk se stal zejména díky Eurípidovi - jedním z bohových hlavních atributů. ${ }^{\mathrm{v}}$ Tento básník také vyjádřil dvojznačnost Erótova působení obrazem dvou jeho luků, $\mathrm{z}$ nichž jeden přináší lásku, dobro a moudrost, zatímco druhý

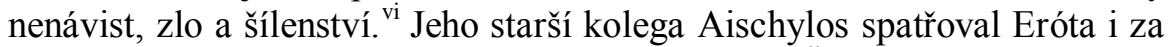

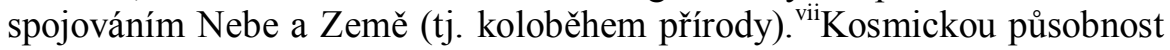
Eróta včetně dvou protikladných stran jeho působnosti několikrát

${ }^{\text {i } D K} 22$ B 51: "Jedno, jsouc neshodné samo se sebou se shoduje, jako spojení u

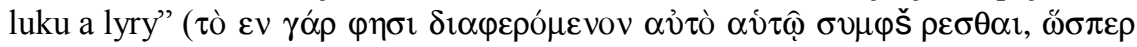

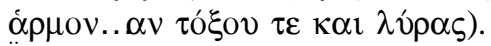

${ }^{\text {ii }}$ K odmítnutí pravděpodobného smyslu viz Symp. 187a-c. Ve většinové verzi vypadá fragment takto: "Nechápou, jak neshodné se sebou souhlasí: nazpět

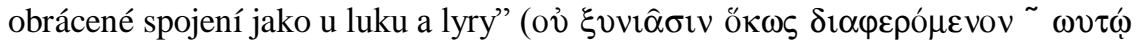

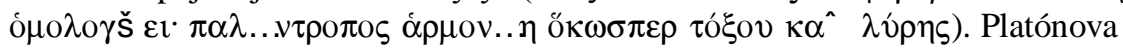
pokroucená parafráze (viz též Soph. 242d-e) byla nicméně velmi vlivná, viz k tomu např. M. Marcovich,Heraclitus. Greek Text with a short Commentary, Merida 1967, s. 124.

iii $D K 22$ B 48: "Luk: jménem život, činem smrt."

${ }^{\text {iv }}$ Furtwängler 1884/88, s. 1351-1354, Rumpf 1966, s. 315, Hermary 1986, s. $907-$ 909, Nr. 659-684, Greifenhagen, 1957, s. 16-18, Abb. 9-12, 18, 20, 22-23, 50.

${ }^{v}$ Eurípidés, Med. 530, 627, 635 a 844, Hipp. 531, frg. 342, 551, 671 a 889, Nauck. Erós s lukem se pak velmi rychle rozšíríil, a to v literatuře (Anth. Pal. V.177, IX.179, XII.109 a 162, Pausaniás II.4.7, Pap. Berlin. 7927, col. II.42-55, aj.; podrobnější seznam výskytů uvádí např. Gruppe 1906, II.1071, pozn. 1), i v ikonografii (Furtwängler 1884/88, s. 1362-1363, Rumpf 1966, s. 314, a Hermary, 1986, 878-881, Nr. 332-361), i když zde existoval ojediněle už dř́ive (viz Hermary, 1986, Nr. 332 z r. 490 př. n. 1.).

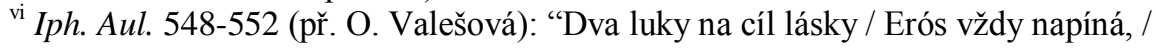
bůh se zlatými vlasy. / Prvním přináší zdar, / druhým zas života zmar."

${ }^{\text {vii } F r g . ~ 44.1-2, ~ N a u c k ~(m l u v c ̌ i ́ m ~ j e ~ A f r o d i ́ t e ́): ~ “ T o u z ̌ i ́ ~ p o s v a ́ t n y ́ ~ U ́ r a n o s ~ p r o n i k n o u t ~}$ Zemi / a erós Zemi pojímá spojit se k sňatku.” Viz též Eurípidés, frg. 898, Nauck, kde se jen místo eróta hovoří přímo o Afrodítě. Do kontextu Eryximachovy řeči řadí tyto verše např. Guthrie 1995, IV.382. 
tematizoval také Sofoklés, podle jehož vlivného názoru tento bůh ovládá vše, lidi i bohy. ${ }^{i}$ Podobně Ferekýdův Zeus proměněný do Eróta složil svět z protikladů a uvedl ho $\mathrm{v}$ jednotu. ${ }^{\mathrm{ii}}$ Jako otec bohů, lidí i zvířat Erós vystupoval i V ptačí kosmogonii Aristofanově, která bývá často považována za parodii starší kosmogonie orfické, iii nebot' otec orfického hnutí Orfeus údajně skládal písně na Eróta a v orfických kosmogoniích z pozdější doby se Erós skutečně vyskytuje na předním místě a podržuje řadu rysů, které se objevují v Aristofanově travestii: Noc-matka, vejce, zlatokrrídlost, vytvoření Úrana a Gé apod. ${ }^{\text {iv }}$

Aristofanés odmítl Eryximachova kosmologického Eróta s tím, že takový bůh by musel mít ohromný kult, zatímco nyní nemá žádný (189c). To je ovšem zjevné zkreslování skutečnosti, ${ }^{v}$ poněvadž Erós v předplatónských i platónských Athénách uctíván zcela nepochybně byl. ${ }^{\text {vi }}$ Neprrímo to dokládá i sám Aristofanés, tř̌ebaže jím vyprávěný mýthos

${ }^{\mathrm{i}}$ Trach. 441 a 781.

ii DK B 3: "Ferekýdés říkal, že když chtěl Zeus tvořit, proměnil se v Eróta, protože složiv svět z protikladů dovedl ho k smíru a lásce a rozesel do všech věci totožnost a jednotu, která proniká celý vesmír." Validita tohoto testimonia je ovšem sporná, viz např. Gruppe 1906, II.1071, pozn. 1, nebo H. S. Schibli, Pherecydes of Syros, diss., The University of Michigan 1984, s. 87-91.

iii OF 1, Kern = Aristofanés, Av. 693-702. Nilsson 1967, I.684-685.

${ }^{\text {iv }}$ OF 305, Kern (Orfeus jako skladatel písní o Erótovi), OF 2 (Erós a Noc: nejisté), OF 28 (asi jen ohlas Hésiodovy Theogonie), OF 37 (Eróta zrodil Chronos), OF 74 (Fanés jako Erós), OF 82 (Erós ve spojení s myslí), OF 83 (ohlas Platónova Symposia), OF 168.9, 169.4, OF 184 (Erós jako Métis a Zeus), OF 170 (Erós vychází z Dia), OF 202 (Erós jako nús). Orph. hymn. 56 na Eróta, Orph. Arg. 14-15 a 419-425 (OT 224, Kern a ad OF 29, s. 100, Kern), aj. O Erótovi v orfismu pojednává napr. W. Staudacher,Die Trennung von Himmel und Erde. Ein vorgriechischer Schöpfungsmythus bei Hesiod und den Orphikern, Darmstadt 1941, s. 96n. O orficích ve spojení s Platónem (a Eryximachovou řečí) srv. W. K. C. Guthrie, Orpheus and Greek Religion, New York $1966^{2}\left(1935^{1}\right)$, kap. IV, a 1995, IV.381, nebo Brisson 2000, s. 48, podle něhož 5 z 6 řečí obsahuje orfické motivy.

v Srv. podobně Eurípidés, Hipp. 538-540. Broneer 1932, s. 49.

${ }^{v i}$ Bůh měl společnou svatyni s Afrodítou $\square v$ Kń $\pi$ orৎ na severním svahu Akropole, (minimálně) od začátku 5. st. byl 4. dne měsíce Múnychiónu pravidelně slaven i jeho svátek (Broneer 1932, s. 43-44 a 49-55, Nilsson 1967, I.525). O 
o kulovitých androgynech, které Zeus rozkrojil na půlky, jež zase Erós svádí dohromady (189d-193a), nemá jako celek žádnou dřivější obdobu. Badatelé však právem upozorn̆ují na několik dílčích analogií a inspirací. Pomineme-li orientální paralely s kulovitými (a vesměs bisexuálními) prvobytostmi, jejichž znalost nelze u Platóna bezpečně prokázat, ${ }^{i}$ jedná se především o čtyřfázovou empedokleovskou zoogonii, v jejíž druhé fázi se v závislosti na intenzitě kosmické lásky - objevují hermafroditi a ve třetí androgyni. ${ }^{\text {ii }}$ Svou roli možná sehrál i bisexuální Fanés orfiků, i když o něm mluví až poplatónské prameny. ${ }^{\text {iii }} \mathrm{S}$ mnohem větší jistotou lze předpokládat vliv př́běhu o Hermafrodítovi, ${ }^{\text {iv }}$ v němž se mísí na jedné straně kult androgynní Afrodíty, kterou prameny nazývaly Afrodítos, ${ }^{\mathrm{v}} \mathrm{s}$ obrazem hermafroditního syna Afrodíty a Herma, který určitým způsobem zvnějšňoval podvojnou povahu své mýthické matky. ${ }^{\text {vi }}$ Někdy v 5 . století př. n. 1. se obě tyto roviny prolnuly, takže v Platónově době už někteří lidé uctívali hermafrodity (plurál!), ${ }^{\text {vii }}$ majíce zčásti na mysli Afrodíta v podobě

athénském kultu Eróta a Afrodíty $\psi \square \theta 0 \rho o \varsigma$ hovoří např. Harpokratión, s.

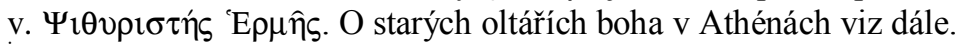

${ }^{i}$ Vliv těchto koncepcí na Platóna předpokládají např. Friedländer 1954, I.100 a 347, pozn. 11, a Baumann 1955, s. 178-179, naproti tomu Guthrie 1995, IV.383, a Koster, 1951, s. 32-35, jsou vůči této hypotéze velmi skeptičtí. K orientálním kulovitým prvobytostem srv. Vítek 2002, s. 161-168.

ii DK A 72, B 61, B 62.4. Dietrich 1939, s. 299-300, Baumann 1955, s. 179-180, Delcourt 1958, s. 113-114, Guthrie 1995, IV.384, Strauss 1996, s. 123, Brisson 2000, s. 200, pozn. 242, Vítek 2002, s. 230-236. Detailněji viz např. D.

O'Brien, L'Empédocle de Platon, in: Revue des études grecques 110, 1997, s. 331338, a Aristophanes' Speech in Plato's 'Symposium': The Empedoclean Background and its Philosophical Significance, in: Plato's Symposium. Proceedings of the Fifth International Plato Symposium in Prague, 12. - 15. October, 2005, ed. A. Havlíček - F. Karfík, Prague : OIKOUMENH 2008.

iii Dietrich 1939, s. 301-309, Baumann 1955, s. 176 a 179, Guthrie 1995, IV.384. Velmi skeptický je Koster 1951, s. 32-33.

${ }^{\text {iv }}$ Guthrie 1995, IV.384.

${ }^{v}$ Aristofanés, frg. 702, Kock, Macrobius, Sat. III.8.2-3, Servius, in Aen. II.632, Lydos, De mens.IV.64.59. Delcourt 1958, s. 75.

${ }^{\text {vi } T o m u ~ n a s v e ̌ d c ̌ u j i ́ ~ i ~ t o t o z ̌ n e ́ ~ c ̌ i ~ p o d o b n e ́ ~ p r ̌ ́ i ́ d o m k y ~ o b o u ~ b o h u ̊, ~ n a p r ̌ . ~} \theta \eta \lambda u ́ \mu \rho \rho \varphi \varsigma$,

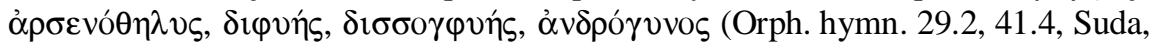

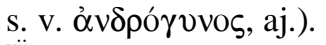

vii Theofrastos, Char. 16. Delcourt 1958, s. 73. 
hermovky ${ }^{i}$ a zčásti Hermafrodita jako androgynního boha, jenž se občas objevuje či ztělesňuje $\mathrm{v}$ lidech, kteří se narodili s oběma pohlavími. ${ }^{i i} \mathrm{Na}$ Eróta jako iniciátora milostných svazků a sňatků upomíná i varianta př́iběhu o Salmakis a Hermafrodítovi, kde bůh vystupuje jako zakladatel manželství a legálního svazku, iii jakkoli je nejisté, zda byla Platónovi známa. iv

Agathón v protikladu k Faidrovi soudil, že Erós je nejmladší a nejblaženější z bohů (195b), nebot' je také “nejkrásnější a nejlepšíi”

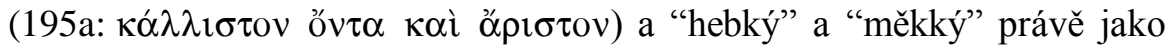
Afrodíté (195c-e), která se v klasické době už pevně prosadila jako jeho matka. 'Tento krásný mladistvý bůžek, jenž prý ustavičně bojuje

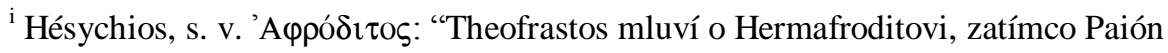
(FGrHist 757 F 1) ve spise Pozoruhodnosti Amathúntu ř́ká, že bohyně na Kypru je vypodobněna ve tvarech muže." Srv. též Alkifrón, Epist. II.35.1, Schepers, Delcourt 1958, s. 74-75, Tümpel 1894, s. 2761 a 2773, Burkert 1985, s. 408, pozn. 5; P. Herrmann, s. v. Hermaphroditos, in: Roscher Lexikon I.2, 1886/90, s. 23152316, a O. Jessen, s. v. Hermaphroditos, in: RE VIII, 1912, s. 717, proto soudí, ž e jméno Hermafrodítos nevzniklo než konfúzí hermovky Afrodíta.

ii Diodóros Sicilský IV.6.5: "Podobný původ jako Priápovi přisuzují některé mýthy takzvanému Hermafrodítovi, který se narodil z Herma a Afrodíty a jeho jméno je složeno z jmen obou jeho rodičů. Někteří uvádějí, že Hermafrodítos je bůh a že se v některých dobách objevuje mezi lidmi. Tehdy se rodí s tělem, které se skládá z muže i ženy, přičemž tělo je krásné a jemné jako žena, ale má sílu a mužnost muže."

iii Jedná se o poému objevenou r. 1995 na inskripci z Halikarnassu (komentované vydání pořídil Isager 1998, s. 1-23), kde na řádcích 18-20 stojí: Salmakis “kdysi našeho hocha / přijala do své laskavé náruče / a vychovala ho, výborného Hermafrodita, jenž pro lidi objevil / sňatek a jako první svázal lože zákonem.”

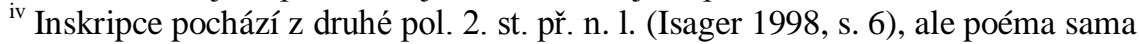
vznikla už o století dříve (Isager 1998, s. 20-22). Stáří motivu nelze určit, ale jeho ojedinělost nasvědčuje málo známé lokální variantě (Isager 1998, s. 12-13). “Standardní” podání př́íběhu uvádí např. Ovidius, Met. IV.285-388 (srv. též Vitruvius II.7.11-12), naproti tomu bohu manželství - vzdor Erótově účasti na svatbách (Hermare 1986, s. 905-906, Nr. 639-649) - nasvědčuje snad jen neemendovaný text Alkifróna, Epist.II.35, Schepers (O. Jessen, s. v. Hermaphroditos, in: RE VIII, 1912, s. 717).

${ }^{v}$ Pausaniás IX.27.2 (př. H. Businská): "Většina lidí považuje Eróta za nejmladšího boha a za syna Afrodítina." Tento názor nebyl cizí ani Platónovi, Phaedr. 242d9- 
s nepěknou neuspořádaností (196a: $\alpha \sigma \chi \chi \mu o \sigma u ́ v \eta)^{\mathrm{i}}$ a "stále prodlévá mezi

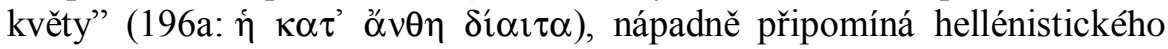
Eróta, sladké, hebké a rozverné děcko, které neposedně poletuje mezi milenci, maminkou a květinami. ${ }^{\text {ii }}$ Ale už Alkmán připodobňoval Eróta $\mathrm{k}$ divokému dítěti, které si hraje nad vrcholky květů a jehož působení je "sladké". iii Podobně ho vykreslil Theognis jako půvabného bůžka uprostřed jarních květů a zeleně, který po zemi rozsévá semínka lásky jako ptáček. iv Také podle Aristofana Erós “oslazuje mysl”. v

Sókratova řeč započíná odmítnutím smysluplnosti otázky, koho je Erós synem (199 D), na niž je ovšem o něco dále poskytnuta svébytná odpověd' (podobně jako na zdánlivé odmítnutí obrazu přetékání moudrosti $\mathrm{v}$ prologu). Sókratés takto reagoval na konkrétní problém, nebot' v důsledku postupující profilace a interpretace boha se různí autoři pokoušeli dohledávat jeho mythologické rodiče tak, aby odpovídali jeho předpokládanému charakteru. Např́iklad Alkaios Eróta nechal zrodit z duhy Íridy a větru Zefýra, ${ }^{\mathrm{vi}}$ podle Simónida byli jeho rodiči Afrodíté a

10: “Což nepokládáš Eróta za syna Afroditina a za jakéhosi boha? - Ovšem, říká se mu tak."

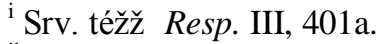

ii Sladkost, něžnost a krása: srv. např.

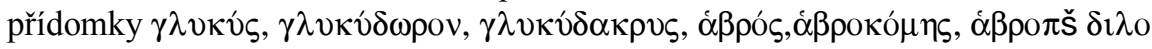

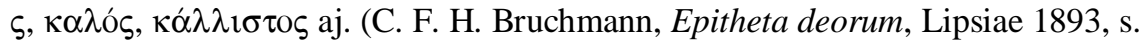
111-117); květy a vegetačni motivy: Xenofón z Efesu I.8, Anth. Pal. XVI.210, Suda, s. v. Zev̂̋ıı, Schol. in Aristoph. Acharn. 991, Hermary 1986, s. 864-846, Nr. 91-167, Rumpf 1966, s. 315, Greifenhagen 1957, s. 7-9, Abb. 1-3 a 14; jako dité a mezi milenci: Hermary 1986, s. 859-861, Nr. 48-70, Rumpf 1966, s. 316-317; také $\mathrm{v}$ jednom z platónských epigramů figuruje Erós jako děcko

(Epigr.XIII.4: $\pi \alpha$ ı́ópiov). Podrobněji viz Nock 1924, s. 152-155.

iii Alkmán, frg. 58, Campbell: “To není Afrodíté, leč divoký Erós, jenž si hraje jak dítě, / spouštěje se nad vrcholky květů;" frg.59, Campbell: Erós "těší, sladce vtékaje do srdce."

iv Theognis 1275-1278 (př. R. Mertlík): "V rozpuku jarního kvítí, když země se skvěje a bují, / tehdy se zjevuje též Erós, ten půvabný bůh. / Tehdy opustí Kypr, svůj překrásný ostrov, a míŕi / k lidem a semínka lásky po světě nosí sem tam."

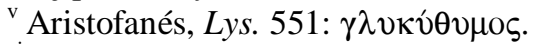

${ }^{v i}$ Alkaios, frg. 327, Edmonds = frg. 13b, Diehl: citát viz dále. Srv. též

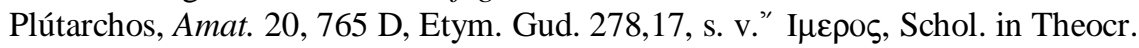


Arés, ${ }^{\mathrm{i}}$ podle Ibyka Afrodíté a Héfaistos ${ }^{\mathrm{ii}}$ legendární Lýk Ólén pokládal za jeho matku bohyni osudu (a porodu) Eileithyii, ${ }^{i i i}$ skladatel tragédií Eurípidés mu určil za otce Dia, ${ }^{\text {iv }}$ Servius ho nechal zplodit - mezi jiným Chaosem a prvotní přirozeností, Cicero Hermem a Artemidou, případně

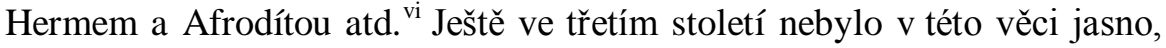
takže básník Antagorás mohl nad bohovou podvojností rozumovat a přijít $\mathrm{s}$ vlastními typy na jeho původ. ${ }^{\text {vii }}$

Diotimina dvojice Penia a Poros na první pohled nemá s žádnou z uvedených rodičovských dvojic nic společného (203b), ${ }^{\text {viii }}$ ale těžko se

XIII.12, Nonnos, Dion. 31.106 a 47.341, aj. U Apuleia, Met. V.6, je Zefýros Erótovým služebníkem.

${ }^{\text {i }}$ Frg. 43, Bergk: "Eróta činí ... Simónidés potomkem Afrodíty a Area: 'ty kruté dítě lstné Afrodíty, jež tebe zrodila úskočnému Areovi."' Viz též Cicero, Nat. deor. III.23.60: citát viz níže.

ii Ibykos, frg. 31, Bergk: " I $\beta$ vко $<\delta \square$ 'A $\varphi \rho о \delta \square \tau \eta \varsigma \kappa \alpha \square ~ ' H \varphi \alpha \square \sigma \tau о v>$. Viz. také Pseudo-Eudokia, Viol. 158, a Servius, in Aen. I.664.

iii Pausaniás IX.27.2 (př. H. Businská): "Lycký Olén naproti tomu ... ve zpěvu na Eileithyi uvádí jako jeho matku právě Eileithyi.” O Ólénově hymnu na Eileithyi mluví také Hérodotos IV.35 a Pausaniás VIII.21.3, ale Eróta v této souvislosti nezmiňují.

iv Eurípidés, Hipp. 534: "Erós, Diův syn."

" Servius, in Aen. I.664: "Simónidés tvrdí, ž e Cupido je natolik pouze synem Venuše, nakolik jiní říkají, že pochází z ní a Vulkána, ještě jiní chtějí, aby byl syn Chaosu a prvotní přirozenosti věcí." Tento výčet ovšem není zrovna nejpřesnější, poněvadž o Simónidovi se ví vcelku jistě, že parthenogenesi Afrodíty nehlásal (Waser 1907, s. 489).

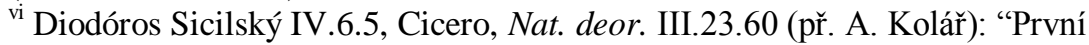
Mílek jest prý synem Merkuria a první Diany, druhý Merkuria a druhé Venuše, třetí, zvaný též Anteros, Marta a třetí Venuše." Podrobnější seznam Erótových rodičů uvádí např̀. Gruppe 1906, II.1071, pozn. 1.

${ }^{\text {vii }}$ Frg. 1, Powell (př. A. Kolář): "Ve své mysli jsem rozdvojen, ježto tvůj původ je sporný, / mám-li tě, Eróte, prvním z bohů prohlásit věčných, nejstarších z veškerých dítek, jež z Ereba zrodila kdysi / královna Noc dole v hlubinách širého Ókeanu. / Mám tě snad nazvat Kypřanky synem nad jiné moudré / anebo Země? Či větrů? Vždyt' tolik zla přinášíśs lidem, / tolik i dobra; proto též dvojí je podoba tvoje." Podobnou nejistotu vyjadřuje i Theokritos XIII.1-2.

viii Jejich jména se před Platónem objevují pouze u Alkmána, frg. 1.14 a 5.2, coll. II.19 (Poros), a Aristofana, Plut. 550-554 (Penia), i kdyžž je otázka, zda je Platón 
pokušení nevidět $\mathrm{v}$ nich Afrodítu s Hermem, nebot’: a) zplodili Hermafrodíta, který nesl znaky obou a Erótovi se v lecčem podobal; ${ }^{i}$ b) v páru působili jako patroni sexuálního spojení kulticky i ikonograficky; ${ }^{\text {ii }}$ c) Penia vykazuje některé rysy Afrodíty Pandémos a Platónova pojetí Afrodíty vůbec; ${ }^{\text {iii }}$ d) Sókratův Erós byl počat na Afrodítiných narozeninách, které byly slaveny zpravidla čtvrtého dne $\mathrm{v}$ měsíci, tj. téhož dne, kdy se $\mathrm{v}$ Athénách konala slavnost na počest skutečného boha Eróta (a nejspíše i Afrodíty), kdy Athéňané obětovávali Hermovi a Hermafrodítovi a kdy bylo také nejlepší pod patronací obou bohů uzavírat sexuální nebo manželské spojení; ${ }^{i v}$ e) Hermés, který s Erótem občas ikonograficky i kulticky splýval, dobře odpovídá

převzal právě odtud (srv. k tomu např. Strauss 1996, s. 192 a 194, nebo Brisson 2000, s. 210, pozn. 392). Někdy bývají pokládáni za personalizaci

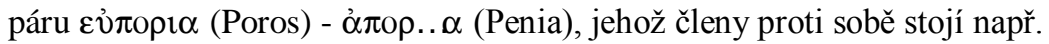
v Phileb. 15c (srv. Symp. 203b9 a 204b7).

${ }^{\mathrm{i}}$ Po celé 4. st. byl Erós představován jako mladík, který se občas natolik podobá Hermafrodítovi, že s ním bývá zaměňován (Rumpf 1966, s. 318). Totéž se dělo i později, srv. např. Eróta, jenž si vyhrnuje šat nad ohanbí stejně, jako to bylo typické pro podobizny Hermafrodíta (Hermary 1986, s. 860, Nr. 58b z 2. st. př. n. 1.).

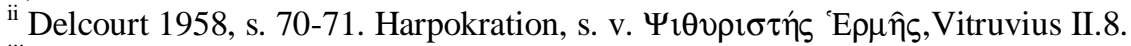
iii Srv. Leg. III, 840e4: u barbarů má velkou moc "nezř́zená Afrodíta" (ó $\alpha \kappa \kappa \tau v$ 'A $\varphi \rho \circ \delta \square \tau \eta v)$, a proto nejsou s to ovládat své pudy. Ve Phileb. 12b-c je Afrodíté identifikována se Slastí ('Hovví), načež je slast odsouzena jako "největší chvástalka" (66c) a protiklad rozumu (66e), nebot' způsobuje bolest, zapomínání a rozruch v duši (63e-f).

${ }^{\text {iv }}$ Afrodítiny narozeniny: LSCG Suppl. 5, Sokolowski, Broneer 1932, s. 49-50, H. W. Parke, Festivals of the Athenians, London 1977, s. 141-143; oběti Hermovi a Hermafrodítovi: Aristofanés, Plut. 1126 plus scholia, Theofrastos, Char. 16, Delcourt 1958 s. 73; ž enitba a sexuální spojení: Hésiodos, Op. 800, Plútarchos, Coniug. praec. 138 C-D, nebo Proklos ap. Schol. in Hes. Op. 798: "Čtvrtý den je zasvěcen Afrodítě a Hermovi, a proto je vhodný pro založení domácnosti,” Delcourt 1958, s. 71-72 a 75 Rudhardt, 1986, s. 32-33. Stojí za zmínku, že Erós býval tradičně přítomen i Afrodítinu zrození, Hésiodos, Theog. 200-202, Hermary 1986, s. 917-918, Nr. 797-804.

${ }^{v}$ Erós byl s Hermem slučován v tzv. Hermeróta, erótovskou hermovku (Rumpf 1966, s. 316, Hermary 1986, Nr. 3-5; kritičtěji k tomu Delcourt 1958, s. 70), přebíral jeho výsostné atributy (Hermary 1986, s. 928-929, Nr. 948-949, Greifenhagen 1957, s. 32, Abb. 39: Erós s typickou hermovskou berlou) nebo 
identifikaci Pora s rozumem a důvtipem, nebot' už Theagenés (6. st.) ho ztotožnil s logem i a v Platónově době byl pokládán za "nejmoudřejšího z bohů" a patrona řečníků a filosofư; ii sám Platón ho vnímal jako patrona a

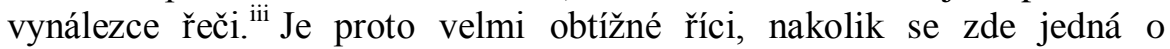
filosofickou alegorii a nakolik o kreativní modifikaci starších mythologicko-náboženských motivů. ${ }^{\text {iv }}$

Za velmi specifický Sókratův krok platí i daimonizace Eróta, ale ani tento př́ípad není zcela bez paralel. Někteří badatelé poukazují na homérské pojetí apersonálního eróta a alternaci pojmů $\theta \varepsilon o ́ \varsigma$ a $\delta \alpha i ́ \mu \omega v$, které označovaly totéž (tj. boha), ${ }^{\mathrm{v}}$ jiní na Bakchylidova "nezdolného

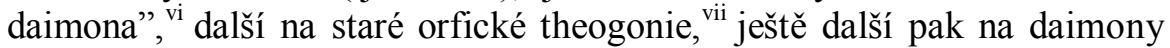
Empedokleovy. ${ }^{\text {viii }}$ To se zdá být asi nejslibnější stopou, poněvadž Empedoklés nazýval filotés a neikos, svou dvojici základních kosmických principů, také daimony, podřadiv je nejvyšší božské síle identifikované

obětoval jeho hermovkám (Hermary 1986, Nr. 462). Ke společnému kultu v gymnasiích viz výše.

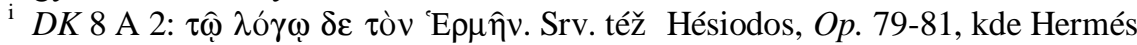
vybavil Pandoru řečí.

ii Aisópos, Fab. 110 (př. V. Bahník): "Zeus stvořil lidi a poručil Hermovi, aby do nich vlil rozum." Aristeidés, Adv. Plat. 13,6-8, Jebb: "Vpravdě také básníci, alespoň podle mého mínění, nepovažují za dárce svého umění (tj. rétoriky)

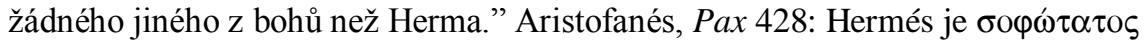
$\theta \varepsilon \hat{\omega} v$. S. Eitrem, s. v. Hermes, in: RE VIII.1, 1912, s. 791-792, P. Stockmeier, s. v. Hermes, in: RACH XIV, 1988, s. 774.

${ }^{\text {iii } C r a t . ~ 407 e 5 ~-~ 408 a 6: ~ " N u z ̌ e, ~ t o t o ~ j m e ́ n o, ~ H e r m e ́ s, ~ p r a v d e ̌ p o d o b n e ̌ ~ n e ̌ j a k ~ s o u v i s i ́ ~}$ s řečí ... veškerá (jeho) činnost souvisí se silou řeči. ... Jméno boha, jenž vymyslel mluvení a řeč, se tedy skládá z obou těchto výrazů."

iv Badatelé zpravidla dávají přednost filosofické alegorii (např. Friedländer 1954, I.191), ale nechybějí ani stoupenci mýthu (např. Baumann 1955, s. 179).

${ }^{v}$ Srv. Reinhardt 1927, s. 66.

${ }^{v i}$ Rumpf 1966, s. 308. Bakchylidés, Dith. XVI.23. Bakchylidovští specialisté však tohoto daimóna identifikují spíše s osudem a kontext výrazu hovoří spíše v jejich prospěch (viz např. D. A. Campbell, Greek Lyric IV, Harvard University Press :

LCL 1992, s. 213, pozn. 8).

vii Baumann 1955, s. 176-179.

viii Např. Reinhardt 1927, s. 66-68. 
mimo jiné s Afrodítou. ${ }^{\mathrm{i}}$ Vzhledem k tomu, že ekvivalence eróta a filotés je velmi nasnadě, ${ }^{\text {ii }}$ nelze zcela vyloučit, že Platón si vyložil empedokleovský pár jako dva protikladné tvary téže daimonské síly (podobně jako Aristotelés), ${ }^{\text {iii }}$ jejímž obrazným ekvivalentem se mu mohl zdát vnitřně i vnějšně protikladný Erós. Erós v Diotimině řeči je sice vylíčen v pozitivních barvách a jakožto prostředník mezi lidským a božským k sobě žádný zřetelný protiklad neváže, ale bylo by asi poněkud neprozíravé vidět $\mathrm{v}$ této pozici jednoznačné překonání všech ostatních řečí a ztotožňovat ji s Platónovým "skutečným” míněním. iv Jásavé přitakání úžasné moci erotického daimona, který dovádí až k nejvyšším cílům, může být docela dobře podobně eroticky dvojznačné jako odmítání přelévání moudrosti a důležitosti pátrání po identitě Erótových rodičů. Obšírná vize úspěchu (otec Poros) nutně implikuje zamlčovanou realitu neúspěchu (matka Penia) a daimón Erós dává smysl jen vedle Eróta boha. ${ }^{v}$ Nikoli každý erós směřuje ke krásnu, dobru a filosofování a slouží jako

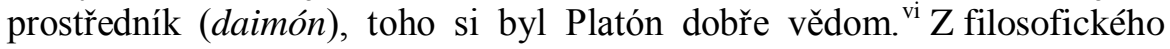
hlediska Diotimina řeč jistě představuje vrchol spisu, avšak z pohledu erótovské aretalogie není než dalším kamínkem v mozaice, nebot' i mantinejská kněžka přizpůsobovala obraz Eróta svým záměrům podobně jako ostatní řečníci.

i $D K 31$ B 59.1. Vítek 2002, I.153-156, 332-334 a zejména 347-348.

ii $D K 31$ ad B 271' “...dokud nepřišla do př́rody touha, když se v ní zpř́ítomnila

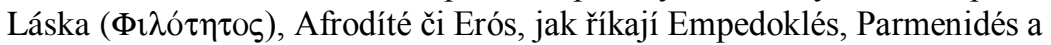
Hésiodos." Srv. Hejduk 2007, s. 28.

iii DK 31 A $37^{1}=$ Met. I.4, 985a29-31: "Empedoklés tedy oproti předcházejícím myslitelům jako první zavedl rozdělení příčiny a nestanovil jediný princip pohybu, nýbrž dva, které jsou si protikladné."

${ }^{\text {iv }}$ To je podle všeho velmi rozšířený postoj, srv. např. Cornford 1950, s. 72n.

${ }^{\vee}$ V tomto smyslu se Erós-bůh z Faidra (Phaedr. 242e) a prvních pěti řečí Symposia s Diotiminým Erótem-daimonem nejen nevylučují, nýbrž spíše doplňují. Srv. Hejduk 2007, s. 41, pozn. 72. K platónskému pojetí Eróta jako daimona viz podrobněji např. Friedländer 1954, I.46-62.

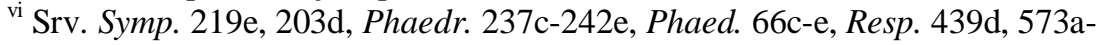
$574 \mathrm{e}, 578 \mathrm{a}$. 
To potvrzuje i závěrečný chvalozpěv na Sókrata, v němž se Alkibiadův učitel a milovník ukazuje jako určité Erótovo ztělesnění. ${ }^{i}$ Alkbiadova řeč tak velmi zvláštním a až obhrouble erotickým způsobem vytváří mýthos o daimonském Sókratovi, ${ }^{\text {ii }}$ který potvrzuje a současně i podrývá to, co řekla Diotima o Erótovi. Tato pozice je o to paradoxnější, že v Sókratově vystoupení převažuje logos, zatímco tradiční (mythologické) motivy se v něm téměr nenalézají. Vedle explicitní podobnosti Sókrata a Siléna (215b, 221e), za něhož je občas dosazován Marsyás, ${ }^{\text {iii }}$ probleskují snad jen dva starší motivy: hermafroditi jako jiné Erótovo vtělení mezi lidmi (viz výše) a Sókratova schopnost svou řečí uchvátit posluchače, rozbušit jim srdce a dostat je do vytržení (215e-216b), která je sice uvedena do analogie se zpěvem Sirén (216a), ale nápadně koresponduje s dovedností jednoho z Erótů, jemuž se rríkalo Hedylogos (Sladkořečník). ${ }^{\text {iv }}$

Po tomto hrubém výčtu potencionálních inspirací, analogií a paralel, které Platón mohl znát a využívat pro svá ztvárnění Eróta, se lze konečně vrátit k úvodní otázce, co athénský filosof se svými "předlohami" v Symposiu činil a co tím sledoval. Různí badatelé nabídli hned několik rozumně vyhlížejících odpovědí, které se spíše doplňují než vylučují, ale přesto postihují Platónův př́stup k Erótovi jen zčásti. Symposion totiž není jen vícerozměrovou aretalogií Eróta, třebaže úvod tak vyznívá a některé řeči či jejich části k tomu mají dosti blízko (Agathón a Alkibiadés). ${ }^{\mathrm{V}}$ Není také pouhým dovedným nahromaděním erótovského materiálu a zohledněním rozštěpu Eróta do několika postav v 5. století, jakkoli jen máloco důležitějšího Platón ponechal stranou. ${ }^{\mathrm{vi}}$ A není ani pouhou umně

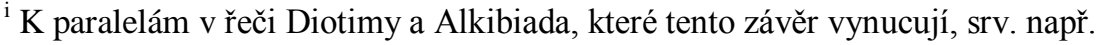
Reinhardt 1927, s. 74, Guthrie 1995, IV.385-386 a 395, Nehamas - Woodruff 1989, s. xxiii-xxiv, Brisson 2000, s. 52-54.

ii Reinhardt 1927, s. 75-76.

iii Strauss 1996, s. 262-264.

${ }^{\text {iv }}$ Hedylogos je důsledkem amplifikace erótů v 5. století, viz např. Afrodítu obletovanou Erótem, Himerem, Pothem a Hedylogem na tzv. Hierónově šálku (Rumpf 1966, s. 313) nebo Afrodítu na voze taženém Pothem a Hedylogem (J. D. Beazley, Attic red-figured Vase Painters, Oxford 1942, s. 833, Nr. 14); samostatný výskyt Hedyloga je jinak velmi vzácný.

${ }^{v}$ Srv. Reinhardt 1927, s. 62, a Nehamas - Woodruff 1989, s. xxv.

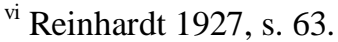


skloubenou filosofickou konstrukcí, která touhu po kráse a moudrosti vynesla $\mathrm{z}$ temného bláta chaotických a rozporných mythologémat do zářivých výšin logu. Platón podle všeho usiloval o více: o pokračování Erótovy dynamické epifanie, která v jeho době ještě zdaleka nebyla hotová.

Leitmotivem všech řečí v Symposiu je rozporná dvojnost a podvojnost v různých formách a stupních: viz záporná tvrzení, která implikují klad, podvojný erós a dva Eróti, dva luky a jeden luk s dvěma účinky, bůh, který je daimón, mladý i starý, personální i apersonální apod. Ba více, tato dvojnost a rozpornost se staly i součástí formální struktury díla. Je známou skutečností, že jednotlivé řeči vytvářejí dvě protikladné skupiny (1-3 a 46) a tři kontrární páry, v nichž jsou zastávána protichůdná stanoviska. ii Prostuduje-li někdo doklady, které se zachovaly o působnosti starověkého Eróta - př́padně i Afrodíty a lásky a touhy vůbec -, těžko mu může uniknout, že určité leitmotivy prostupují nejen výstupy všech Platónových řečníků, nýbrž i reálný kult, mythologii a ikonografii. Vábení k jedné straně a podobě věcí za ustavičné skryté nebo zjevné př́ítomnosti strany a podoby opačné, neustálé proplétání rozpornosti, netotožnosti a záporu se souladem, identitou a afirmací, rozverné přeskakování na místě mezi dvojitostí a podvojností, to vše se v Erótově (a zčásti i Afrodítině) epifanii nejen opakovaně objevuje, ale představuje v ní cosi základního. Rilke ve svých Sonetech Orfeovi dobře vystihl Erótovu povahu, když o něm řekl, že "sein Sinn ist Zwiespalt". iii Tento zvláštní rozpor mohl být různě zvnějšňován do dvou protichůdných tvarů, nebo zůstávat skryt v prríbězích o bohově původu či působnosti, ale vpodstatě se jednalo jen o různé výrazy téhož.

Platón v Symposiu občas používal tradiční motivy netradičním způsobem, občas si s nimi i ironicky pohrával a paradoxně je křivil podle

\footnotetext{
${ }^{i}$ Nehamas - Woodruff 1989, s. xv-xvii: první skupina (č. 1-3) víceméně konvečně chválí Eróta, druhá skupina (č. 4-6) se jím zabývá z hlediska subjektu a jeho vztahu k jinému subjektu.

${ }^{\text {ii }}$ Reinhardt 1927, s. 55, Brisson 2000, s. 39-47: s. 40-41: Faidros (1) a Agathón (5); s. 41-43: Pausaniás (č. 2) a Eryximachos (č. 3); s. 43-47: Aristofanés (č. 4) a Sókratés (č. 6). Tyto protiklady je ovšem možné vést i jinými směry, např. Guthrie 1995, IV.381, klade do protikladu řeč Pausaniy (č. 2) a Sókratovy Diotimy (č. 6).

iii R. M. Rilke, Die Sonette an Orpheus I.3.3.
} 
svých postav, ale takřka vždy s velkým citem pro možné a s hlubokým pochopením elementárního modu erótovského bytí. Jeho dílo proto není pouhým spisem $o$ Erótovi, nýbrž je literárně-filosofickým ztělesněním Eróta a jeho podvojné povahy a působivosti podobně, jako jím byl učiněn Sókrates v Diotimině a Alkibiadově řeči. Symposion je brilantní ukázkou mnohovrstevného logu, ale současně i multifasetovou manifestací mýthu, aniž lze říci, kde jedno začíná a druhé končí. Je svéráznou intelektuální mapou své doby, jejíž vybraní reprezentanti se vynořují z erótovského zrcadla při jeho stále novém vytváření a přetváření. Ale především je epifanií Eróta od prvního řádku do posledního, jíž se žádná z těch dřívějších ani pozdějších nemůže rovnat. 


\section{Literatura:}

Baumann, Hermann, 1955, Das doppelte Geschlecht. Ethnologische Studien zur Bisexualität in Ritus und Mythos, Berlin : Dietrich Reimer.

Brisson, Luc, $2002^{2}\left(1998^{1}\right)$, Le Banquet. Traduction inédite, introduction et notes, Paris : GF Flammarion.

Broneer, Oscar, 1932, "Eros and Aphrodite on the North Slope of the Acropolis in Athens", Hesperia 1, s. 31-55.

Burkert, Walter, Greek Religion, Harvard University Press 1985.

Cornford, Francis MacDonald, 1950, "The Doctrine of Eros in Plato's Symposium", in: Guthrie, W. K. C. (ed.), The Unwritten Philosophy and Other Essays, Cambridge University Press, s. 68-80.

Delcourt, Marie, 1958, Hermaphrodite. Mythes et rites de la Bisexualité dans l'Antiquité classique, Paris : PUF.

Dietrich, Ernst Ludwig, 1939, “Der Urmensch als Androgyn”, Zeitschrift für Kirchengeschichte 58, dritte Folge IX, Heft III-IV, s. 297-345.

Dover, Keneth James, Greek Homosexuality, Cambridge (Mass.) : Harvard University Press $1989\left(1978^{1}\right)$.

Friedländer, Paul, 1954, Plato, Band I. Seinswahrheit und Lebenswirklichkeit, Berlin : Walter de Gruyter.

Furtwängler, Adolf, 1884/88, s. v. Eros, in: Roscher Lexikon I.1, s. 13391372.

Greifenhagen, Adolf, 1957, Griechische Eroten, Berlin : Walter de Gruyter. 
Gruppe, Otto, 1903 (I) a 1906 (II), Griechische Mythologie. München : C. H. Beck'sche Verlagsbuchhandlung.

Guthrie, William Keith Chambers, 1995 (1975 $)$, A History of Greek Philosophy IV. Plato: The Man and his Dialogues earlier Period, Cambridge : Cambridge University Press, s. 365-396.

Hejduk, Tomáš, 2007, Od Eróta kfilosofii. Studie o Erótu se zřetelem $k$ Sókratově filosofii, Amfibios 7, Praha : Pavel Mervart.

Hermary, Antoine - Cassimatis, Hélène - Vollkommer, Reiner, 1986, s. v. Eros, in: LIMC (= Lexicon iconographicum mythologiae classicae) III.1-2, Zürich - München, s. 850-942.

Isager, Signe, "The Pride of Halicarnassos. Editio Princeps of an Inscription from Salmakis", Zeitschrift für Papyrologie und Epigraphk 123, 1998, s. 1-23.

Kirk, Geoffrey S. - Raven, John E. - Schofield, Malcolm, 2004, Předsókratovští filosofové, Praha : OIKOYMENH.

Koster, W. J. W., Le mythe de Platon, de Zarathustra et des Chaldéens. Étude critique sur les relations intellectuelles entre Platon et l'Orient, Leiden : Brill 1951.

Merill, Robert V., 1944, "Eros and Anteros", Speculum. A Journal of Mediaeval Studies 19/3 (July), s. 265-284.

Nehamas, Alexander - Woodruff, Paul, 1989, Plato, Symposium, Indianapolis - Cambridge : Hackett Publishing Company.

Nilsson, Martin Pearson, $1967^{3}\left(1955^{1}\right)$, Geschichte der griechischen Religion, München : C. H. Beck'sche Verlagsbuchhandlung.

Nock, Arthur Darby, 1924, "Eros the Child”, The Classical Review 38/7-8 (Nov. - Dec.), s. 152-155. 
Onians, Richard Bronxton, $1991^{2}\left(1951^{1}\right)$, The Origins of European Thought, Cambridge : Cambridge University Press.

Reinhardt, Karl, 1927, Platons Mythen, Bonn : Verlag von Friedrich Cohen, s. 53-76.

Rudhardt, Jean, 1986, Le rôle d'Éros et d'Aphrodite dans les cosmogonies grecques, Paris PUF.

Schneider, Carl (literarisch) - Rumpf, Andreas (in der Kunst), 1966, s. v. Eros I-II, in: RACH VI, s. 306-312 a 312-342.

Strauss, Leo, 2001², On Plato's Symposium, Chicago - London : The University of Chicago Press.

Tümpel, Karl (kult) - Dümmler, Ferdinand (ikonografie), 1894, s. v. Aphrodite, in: RE I.2, s. 2729-2787.

Vítek, Tomáš, 2002, Empedoklés I. Studie, Praha : Herrmann a synové.

Waser, Otto, 1907, s. v. Eros, in: RE VI, s. 484-542. 